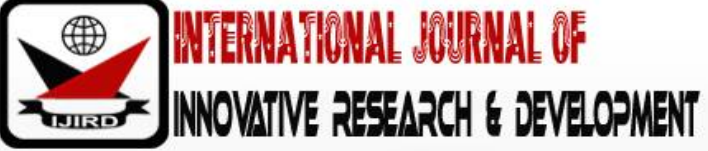

ISSN 2278 - 0211 (Online)

\section{Role of Firm Size on the Relationship between Knowledge Management Practices and Non-Financial Performance: Evidence from Family Firms}

\author{
Dr. Maurice Ochieng Oyoo \\ Lecturer, School of Business and Human Resource Development, Rongo University, Kenya
}

\begin{abstract}
:
The relationship between knowledge management and non-financial performance has attracted considerable interest in the past few decades, yet the role of the size of a firm on this relationship remains largely unexplored. I argue that the relationship between knowledge management practices and non-financial performance moderated by firm factors like the number of employees in an organization, asset valuation and market share. A survey of 75 is carried out with family firms in Migori County, Kenya. Findings reveal that firm size has a moderating effect on the association between knowledge management practices and non-financial performance. The study contributes to theory by developing a model where knowledge management has a relationship with non-financial performance but is moderated by firm factors.
\end{abstract}

Keywords: Knowledge management, non-financial performance, firm size, family firms

\section{Introduction}

Ali, Mukulu, Kihoro and Nzulwa (2016) argue that whereas firm size remains a predictor of knowledge management and firm performance relationship, it does not moderate the relationship between management participation in knowledge management and firm performance. This study therefore seeks to establish whether it moderates the relationship between knowledge management practices and non-financial performance

Non-financial performance measures comprise of variables such as customer satisfaction, job satisfaction, management control systems, and others that are not captured by financial systems (Malgharni et al., 2010). Non-financial performance measures in the current study are customer satisfaction, customer retention, employee satisfaction, employee retention, product quality, and service quality. Firm size refers to the scale of operation associated with a social system. For most enterprises, however, the scale of operation is easily captured by the number of employees contracted, monetary value of the assets in the organization's possession, and the level of expenditure in the organization (Price, 1972). In addition, a number of studies view an organization's size in terms of number of people - or members - that compose it, or workforce that constitute it (Bozkurt, Kalkan \& Arman, 2014). The size of a firm has a critical role to play on an enterprise's performance. In fact, it is revealed by most studies that size of the firm leads to hiring of more experienced workforce equipped with the benefits of learning, and are therefore not prone to the liabilities of smaller firms (Stinchcombe, 1965). They are therefore expected to experience significant changes in performance compared to other firms.

Dang and Li (2015) observes that firm size continues to attract attention as one of the most fundamental firm characteristics, despite virtually no significant study assessing how sensitive corporate finance reacts to different size attributes of an organization. The current study, however, uses firm components such as market capitalization of firm, total size of the firm's assets and total sales volume to define an organization's size. Moreover, the study advises against being overly focused on size proxies such as market cap. Naturally, therefore, the study supports earlier assertion that the measure for firm size should be sufficiently robust, and that different size measures have different effects on outcome variables. Chandrapala and Knápková (2013) in a study of Czech Republic, investigated internal factors and the role they play at bringing about financial performance. In particular, the study examined the role of select factors on an organization's financial performance. Nine hundred and seventy-four enterprises in The Czech Republic were investigated from the year 2005 to the year 2008, with data sourced from a database in Albertina. Arising from the study, it was evident that the explanatory powers of the two models were low, thereby occasioning the need for further research geared at improving the power of statistic occasioned by the model. The findings are important for managers and investors in planning for investments and operational activities aimed at enhanced profitability. Internal factors as used in the study is also too broad a term; and this study makes it more explicit by investigating firm size as one of those factors pursued by Chandrapala and Knápková (2013). Knowledge management practices are hypothesized to influence non-financial performance. The independent variables knowledge management practices and the dependent variable is non-financial performance. Firm size moderates the relationship. The relationship is presented in Figure 1. 


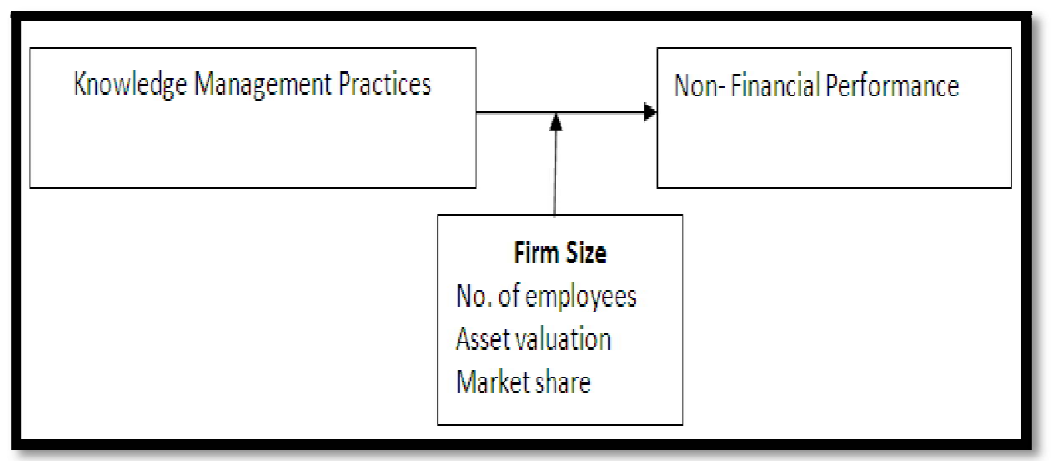

Figure 1: Conceptual Framework

Source: Researcher (2019)

\section{Method}

The moderating effect is tested as illustrated in models 1 and 2 in the discussion hereafter: Firstly, an equation is generated, and is shown in Model 1.

NFP $=\beta_{0}+\beta_{1}$ SKMPs $+\beta_{2}$ FS $+\varepsilon$

Model 1 presents the scenario with the independent variable and dependent variable, but without the dummy variable (product of KMPs and FS). The Model is used to generate a model summary - that displays the change in R squared - which is consequently compared to the R squared in the subsequent model (Model 2). Having developed model 1, the next task is to develop the subsequent model (Model 2) which is compared to Model 1 to generate results to be compared to elicit the situation on the moderation status.

$\mathrm{NFP}=\beta_{0}+\beta_{1}$ SKMPs $+\beta_{2} \mathrm{FS}+\beta_{3} \mathrm{SKMPs} * \mathrm{FS}+\varepsilon$

Where: NFP $=$ Non- financial performance

$\beta_{0}=$ Constant term

$\beta_{1}, \beta_{2}=$ Coefficients of SKMPs and FS

SKMPs $=$ Strategic knowledge management practices

FS $=$ Firm size

$\varepsilon=$ Error term

Model 2 is the ultimate model that generates model summaries reflecting the change in R squared - which is subsequently used to establish the statistical significance of the interaction term (the product of KMPs and FS). Besides, it is also used to determine whether firm size moderates the association between knowledge management practices and non-financial performance. The R squared generated in model 1 and 2 explains the percentage increases in variations arising due to the incorporation of interaction term (Laerd Statistics, 2018). If the probability value is less the critical value - as represented by the Sig. F Change column in the output table - then it is concluded that the moderator term, moderates the relationship existing between strategic knowledge management practices and non-financial performance.

\begin{tabular}{|c|c|c|c|c|}
\hline \multirow{2}{*}{ Variable } & Cronbach's & No. of & \multicolumn{2}{|c|}{ Scale Statistics } \\
\cline { 4 - 5 } & Alpha & Items & Mean & Std. Deviation \\
\hline Knowledge management practice & 0.902 & 15 & 58.25 & 9.72 \\
\hline Firm Size & 0.789 & 3 & 5.28 & 2.07 \\
\hline Non-Financial Performance & 0.955 & 20 & 83.07 & 14.43 \\
\hline
\end{tabular}

Table 1: Reliability Test Results

Source: Survey Data (2019)

Arising from the results in Table 1, knowledge management practices has a Cronbach's alpha score of 0.902 with 15 items, a mean of 58.25 and a standard deviation of 9.72. Firm size has a Cronbach's alpha score of 0.789 with three items. Non-financial performance has a Cronbach's alpha score of 0.955 with 20 items. Clearly, all the survey variables have Cronbach alpha values exceeding 0.7 as recommended by Cooper and Schindler (2007) who considers a reliability scores of 0.7 and above as pointers to reliable instrumentation.

\section{Research Design and Data Collection Procedures}

Survey method is used for the study since it facilitates a rapid turnaround in collection of field data by identifying the salient features of a largely inherent group - population wise -from a relatively small group of cases in consideration (Creswell, 2014). In particular, cross sectional survey design is employed for the study.

The target population are the 167-family owned MSMEs in Migori County. Proportionate stratified sampling is used to obtain a sample of 118 respondents. Proportionate stratified sampling is deemed appropriate for the study as recommended by Kumar (2011) who considers stratified sampling appropriate when the population is not homogenous in certain characteristics of interest. Moreover, a sample estimation relationship is adopted as recommended by Yamane (1967). According to the relationship, at 95\% confidence level, 118 respondents are targeted. The sample of 118 respondents, translated to 70.66 percent of the initially targeted population. The sample is arrived at as a result of the equation presented hereafter. 
$\mathrm{n}=\frac{\mathrm{N}}{1+\mathrm{N}\left(\mathrm{e}^{2}\right)}$

Where: $\mathrm{n}$ refers to the sample size, $\mathrm{N}$ stands for population size, and e refers to the level of precision (also sampling error, and is at 0.05 ).

Therefore,

$$
\mathrm{n}=\frac{167}{1+167(0.0025)}=117.81305
$$

\subsection{Hypothesis Testing}

On the basis of the study objectives, associated hypotheses are developed. The statistical model for each hypothesis to be tested is shown across each hypothesis in Table 2 .

\begin{tabular}{|c|c|c|c|}
\hline Objective & Hypothesis & Statistical Model & $\begin{array}{c}\text { Hypothesis Test and Decision } \\
\text { Rule }\end{array}$ \\
\hline $\begin{array}{l}\text { Determine the } \\
\text { moderating effect } \\
\text { of FS on the } \\
\text { relationship } \\
\text { between KMPs and } \\
\text { NFP of family } \\
\text { MSMEs in Migori } \\
\text { County }\end{array}$ & $\begin{array}{l}\text { FS has no moderating } \\
\text { effect on the } \\
\text { relationship } \\
\text { between KMPs and } \\
\text { NFP of family MSMEs } \\
\text { in Migori County. }\end{array}$ & 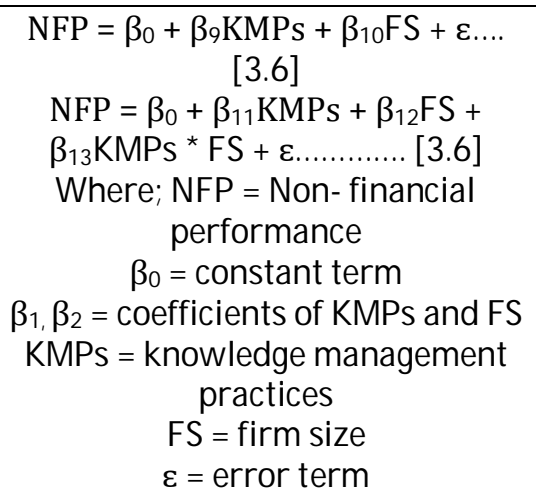 & $\begin{array}{c}\mathrm{H}_{05}: \mathrm{B}_{9}, \mathrm{~B}_{10}, \mathrm{~B}_{11}, \mathrm{~B}_{912}, \mathrm{~B}_{13}=0 \\
\mathrm{H}_{25}: \mathrm{B}_{9}, \mathrm{~B}_{10}, \mathrm{~B}_{11}, \mathrm{~B}_{912}, \mathrm{~B}_{13} \neq 0 \\
\text { Reject } \mathrm{H}_{05} \text { if } \mathrm{p} \leq 0.05, \text { otherwise fail } \\
\text { to reject null at } \alpha=0.05\end{array}$ \\
\hline
\end{tabular}

Table 2: Summary of Data Analysis

\section{Discussion}

Source: Researcher (2019)

Knowledge management practicesare assessed using a set of five measures namely knowledge sharing culture, management of intellectual capital, knowledge creation. The moderating variable is firm size. The dependent variable is non-financial performance. Table 3 presents the non-financial performance dimensions, the number of respondents involved, means, standard deviations, t- values, degrees of freedom, and the accompanying $p$-values.

\begin{tabular}{|c|c|c|c|}
\hline & N & Mean & Std. Deviation \\
\hline Knowledge management practices & 75 & 4.18417 & 0.727099 \\
\hline Firm Size & 75 & 2.70933 & 0.613623 \\
\hline Non-Financial Performance & 75 & 4.15333 & 0.715954 \\
\hline
\end{tabular}

Table 3: Descriptive Statistics for Study Variables

Source: Survey Data (2019)

Arising from the results in Table 3, and on a scale of 1 to 5 (where 5 represents completely agree and 1 stands for completely disagree), the means for study variables vary between 2.70933 and 4.18417 .

\begin{tabular}{|c|c|c|c|c|c|c|c|c|}
\hline Model & $\mathbf{R}$ & R Square & \multicolumn{2}{|c|}{$\begin{array}{l}\text { Adjusted R } \\
\text { Square }\end{array}$} & $\begin{array}{l}\text { Std. Error of the } \\
\text { Estimate }\end{array}$ & & & \\
\hline \multirow[t]{2}{*}{1} & $0.927 \mathrm{a}$ & 0.858 & & .852 & 0.275016 & & & \\
\hline & Todel & \multicolumn{2}{|c|}{ Sum of Squares } & $\mathrm{df}$ & Mean Square & $\mathrm{F}$ & Sig. & \\
\hline \multirow[t]{3}{*}{1} & Regression & \multicolumn{2}{|c|}{32.562} & 3 & 10.854 & 143.506 & $0.000^{\mathrm{b}}$ & \\
\hline & Residual & \multicolumn{2}{|c|}{5.370} & 71 & 0.076 & & & \\
\hline & Total & 37.9 & & 74 & & & & \\
\hline \multirow{2}{*}{\multicolumn{4}{|c|}{ Model }} & \multicolumn{2}{|c|}{ Unstandardized Coefficients } & $\begin{array}{l}\text { Standardized } \\
\text { Coefficients }\end{array}$ & $\mathbf{T}$ & Sig. \\
\hline & & & & $\mathrm{B}$ & Std. Error & Beta & & \\
\hline \multirow[t]{4}{*}{1} & \multicolumn{3}{|c|}{ (Constant) } & -0.107 & 0.208 & & -.515 & 0.608 \\
\hline & \multicolumn{3}{|c|}{ Knowledge Sharing Culture } & 0.490 & 0.095 & 0.464 & 5.151 & 0.000 \\
\hline & \multicolumn{3}{|c|}{$\begin{array}{c}\text { Management of Intellectual } \\
\text { Capital }\end{array}$} & 0.001 & 0.066 & 0.002 & 0.022 & 0.983 \\
\hline & Knowl & que Creatior & & 0.544 & 0.092 & 0.502 & 5.888 & 0.000 \\
\hline
\end{tabular}

Table 4: Regression Results for Knowledge Management Practices on Non-Financial Performance

a. Dependent Variable: Non-Financial Performance 
In Table 4, R square is 0.858 , which implies that $85.8 \%$ of the variations in NFP are explained by knowledge management practices. The implication is that there is a high degree of correlation between the variables. The Table indicates that the regression model predicts the dependent variable significantly well. Since, $p<0.0005$, the regression model statistically significantly predicts non-financial performance and is a good fit for the data. Based on the coefficients, the regression equation is NFP $=-0.107+0.490 \mathrm{KSC}+0.001 \mathrm{MIC}+0.544 \mathrm{KC}$ Where: $\mathrm{NFP}=$ Non-financial performance, MIC $=$ Management of intellectual capital, $\mathrm{KC}=$ Knowledge creation.

Table 5 presents a summary of the model explaining the addition of the interaction term to the initial model comprising of the independent and moderating variable.

\begin{tabular}{|c|c|c|c|c|c|c|c|c|c|}
\hline \multirow[t]{2}{*}{ Model } & \multirow[t]{2}{*}{$\mathbf{R}$} & \multirow{2}{*}{$\begin{array}{c}\text { R } \\
\text { Square }\end{array}$} & \multirow{2}{*}{$\begin{array}{l}\text { Adjusted } \\
\text { R Square }\end{array}$} & \multirow{2}{*}{$\begin{array}{l}\text { Std. Error } \\
\text { of the } \\
\text { Estimate }\end{array}$} & \multicolumn{4}{|c|}{ Change Statistics } & \multirow[b]{2}{*}{$\begin{array}{c}\text { Sig. F } \\
\text { Change }\end{array}$} \\
\hline & & & & & $\begin{array}{c}\mathbf{R} \\
\text { Square } \\
\text { Chanqe }\end{array}$ & $\begin{array}{c}\mathbf{F} \\
\text { Change }\end{array}$ & df1 & df2 & \\
\hline 1 & $0.931^{\mathrm{a}}$ & 0.867 & 0.863 & 0.264631 & 0.867 & 234.825 & 2 & 72 & 0.000 \\
\hline 2 & $0.936^{b}$ & 0.876 & 0.870 & 0.257719 & 0.009 & 4.914 & 1 & 71 & 0.030 \\
\hline
\end{tabular}

Table 5: Regression Model Summary for Moderation

Source: Survey Data (2019)

Predictors: (Constant), Firm Size, Strategic Knowledge Management Practices

Predictors: (Constant), Firm Size, Strategic Knowledge Management Practices, FS X Skmps

Dependent Variable: Non-Financial Performance

In Table 5, a change in R square of 0.009 (that is 0.876 less 0.867 ) is occasioned following the inclusion of the interaction term knowledge management practices and firm size into the initial model with only independent and moderator variable. The same figure recurs for the R square change column in Model 2 as 0.009 . Since R squared change value is $0.9 \%(0.009 \times 100 \%)$, it is concluded that the inclusion of the interaction term firm size improves the prediction of non-financial performance. Table 6 presents the analysis of variance results for moderation.

\begin{tabular}{|c|c|c|c|c|c|c|}
\hline \multicolumn{2}{|c|}{ Model } & $\begin{array}{c}\text { Sum of } \\
\text { Squares }\end{array}$ & Df & $\begin{array}{c}\text { Mean } \\
\text { Square }\end{array}$ & F & Sig. \\
\hline \multirow{2}{*}{1} & Regression & 32.890 & 2 & 16.445 & 234.825 & $0.000^{\mathrm{b}}$ \\
\cline { 2 - 7 } & Residual & 5.042 & 72 & 0.070 & & \\
\cline { 2 - 7 } & Total & 37.932 & 74 & & & \\
\hline \multirow{2}{*}{2} & Regression & 33.216 & 3 & 11.072 & 166.698 & $0.000^{\mathrm{c}}$ \\
\cline { 2 - 7 } & Residual & 4.716 & 71 & 0.066 & & \\
\cline { 2 - 7 } & Total & 37.932 & 74 & & & \\
\hline \hline
\end{tabular}

Table 6: ANOVA Test Results for Moderation Analysis

Source: Survey Data (2019)

Dependent Variable: Non-Financial Performance

Predictors: (Constant), Firm Size, knowledge management practices

Predictors: (Constant), Firm Size, knowledge management practices, FS x KMPs

In Table 6, the unmediated model is statistically significant $F(2,72)=234.825, p<0.005$. Similarly, the mediated model is statistically significant $F(3,71)=166.698, p<0.005$. It is therefore concluded that both Model 1 and 2 predict non-financial performance significantly well. The results in Table 6 show that the R square change value generated as a result of the inclusion of firm size is 0.009 . The proportion 0.009 implies that $0.9 \%$ is the variation explained by the addition of the interaction term. The results obtainable from the Sig. F Change column also indicate that the increase is statistically significant $(\mathrm{p}<0.05)$. It is therefore concluded that firm size moderates the relationship between strategic knowledge management practices and non-financial performance. 


\begin{tabular}{|c|c|c|c|c|c|c|c|c|c|c|}
\hline \multirow{2}{*}{\multicolumn{2}{|c|}{ Model }} & \multicolumn{2}{|c|}{$\begin{array}{l}\text { Unstandardized } \\
\text { Coefficients }\end{array}$} & \multirow{2}{*}{$\begin{array}{c}\begin{array}{c}\text { Standardized } \\
\text { Coefficients }\end{array} \\
\text { Beta }\end{array}$} & \multirow[t]{2}{*}{$\mathbf{T}$} & \multirow[t]{2}{*}{ Sig. } & \multicolumn{2}{|c|}{$\begin{array}{l}\text { 95.0\% Confidence } \\
\text { Interval for B }\end{array}$} & \multicolumn{2}{|c|}{$\begin{array}{l}\text { Collinearity } \\
\text { Statistics }\end{array}$} \\
\hline & & B & $\begin{array}{l}\text { Std. } \\
\text { Error }\end{array}$ & & & & $\begin{array}{l}\text { Lower } \\
\text { Bound }\end{array}$ & $\begin{array}{l}\text { Upper } \\
\text { Bound }\end{array}$ & Tolerance & VIF \\
\hline \multirow[t]{3}{*}{1} & (Constant) & -0.107 & 0.199 & & -.538 & 0.592 & -0.504 & 0.290 & & \\
\hline & KMPs & 0.417 & 0.106 & 0.394 & 3.949 & .000 & 0.207 & 0.628 & 0.185 & 5.400 \\
\hline & Firm Size & 0.605 & 0.108 & 0.560 & 5.605 & 0.000 & 0.390 & 0.820 & 0.185 & 5.400 \\
\hline \multirow[t]{4}{*}{2} & (Constant) & 0.198 & 0.238 & & 0.832 & 0.408 & -0.276 & 0.671 & & \\
\hline & KMPs & 0.268 & 0.123 & 0.253 & 2.176 & 0.033 & 0.022 & 0.513 & 0.130 & 7.721 \\
\hline & Firm Size & 0.590 & 0.105 & 0.546 & 5.603 & 0.000 & 0.380 & 0.800 & 0.184 & 5.422 \\
\hline & FS x KMPs & 0.033 & 0.015 & 0.180 & 2.217 & 0.030 & 0.003 & 0.063 & 0.267 & 3.750 \\
\hline
\end{tabular}

Table 7: Moderation Test Coefficients

Dependent Variable: Non-Financial Performance

Source: Survey Data (2019)

Based on the results in Table 7, a non-moderated multiple regression equation connecting the independent and the moderator variable is expressed as follows

$\mathrm{NFP}=-0.107+0.417 \mathrm{KMPs}+0.605 \mathrm{FS}$

Arising from the results posted in the coefficient Table 7, a moderated multiple regression equation connecting the independent, moderator and dependent variable is expressed as follows

$\mathrm{NFP}=0.198+0.268$ SKMPs +0.590 FS +0.033 FS x KMPs .

Where:

NFP $=$ Non- financial performance

KMPs = Knowledge management practices

FS $=$ Firm size

FS $x$ KMPs = Interaction term i.e. the product of knowledge management practices and firm size.

\section{Conclusions}

Since firm size moderates the relationship between knowledge management practices and non-financial performance, the implication is that improved skillful employees, expansion of asset worth, and expanded market shares by organizations should go a long way in improving their non-financial performance.

\section{References}

i. Ali, M. J., Mukulu, E., Kihoro, J. M., \& Nzulwa, J. D. (2016). Moderating effect of firm size on the relationship between management participation and firm performance. The Strategic Business and Change Journal of Management, 3(3), 223-238.

ii. Atiyah, L. (2016, Nov 3th- 4th). Product quality and its impact on customer satisfaction: A field study in Diwaniyah Dairy Factory. Proceedings of the $10^{\text {th }}$ International Management Conference "Challenges of modern management", Bucharest, Romania.

iii. Atul, S. (2017, May). In E. Ondieki (2018, January 7). Which way family business? Is it time to go professional? Nation Newspaper, 20-21.

iv. Brooking, A. (1997). Intellectual capital. International Thompson Business Press.

v. Cooper, B. K. (2015). An introduction to moderated mediation. Department of Management,

vi. Monash University.

vii. Cooper, D., \& Schindler, P. (2001). Business research methods. Boston: McGraw-Hill.

viii. Cooper, D. R., \& Schindler. P. S. (2008). Business research methods (8th ed.). USA:

ix. McGraw-Hill.

x. Creswell, J. W. (2014). Research design: Qualitative, quantitative and mixed methods approaches (4th ed.). Los Angeles, LA: SAGE Publications Ltd.

xi. Dang, C. D., \& Li, F. (2018). Measuring firm size in empirical corporate finance. Journal of

xii. Banking and Finance, 8(6), 159- 176.

xiii. Eckhouse, J. (1999). Sharing knowledge isn't easy yet. Information week, 99.

xiv. Engineering Statistics Handbook. (2012). Kolmogorov-Smirnov goodness-of-fit test.

xv. Retrieved from https:/ / www.itl.nist.gov/ div898/ handbook/ eda/ section3/ eda35g.html

xvi. Garson, G. D. (2012). Testing statistical assumptions. Statistical Associates Publishing:

xvii. North Carolina, USA.

xviii. Giampaoli, D., Ciambotti, M., \& Bontis, N. (2017). Knowledge management, problemsolving and performance in top Italian firms. Journal of Knowledge Management, 21(2), 355-375.

xix. Goff, R., \& Jones, G. (1996). What holds the modern company together? Harvard Business

xx. Review, 133-148. 
xxi. Heathfield, M. S. (2016). Employee satisfaction: Make employee satisfaction surveys successful. Retrieved fromhttps:/ / www.thebalance.com/ employee-satisfaction-1918014. retrieved 03.08.2017.

xxii. Imran A., Ata U. M., \&Murad A. (2018). Impact of knowledge sharing and absorptive capacity on project performance: The moderating role of social processes. Journal of Knowledge Management, 22(2) , 453-477.

xxiii. Inkinen, H. (2015). Review of empirical research on intellectual capital and firm performance. Journal of Intellectual Capital, 16(3), 518-565.

xxiv. Janus, S. S. (2016). Becoming a knowledge-sharing organization: A handbook for scaling up solutions through knowledge capturing and sharing. The World Bank 1818 H Street NW: Washington, DC 20433.

xxv. Kumar, R. (2011). Research methodology: A step- by- step guide for beginners (3rd ed.).

xxvi. New Delhi: Sage.

xxvii. Lani, J. (2017). Statistical solutions: Assumptions of linear regressionwith Expert guidance every step. Retrieved from: http:/ / www.statisticssolutions.com/ assumptions-of-linear-regression.

xxviii. Malgharni, A. M., Soomasundaram, N. R., \& Multaiyah, S. (2010). Non-financial performance for firm's evaluation. European Journal of Economics, Finance and Administrative Sciences, 23(1), 123-138.

xxix. Muigai, R. G., \& Muriithi, J. G. (2017). The moderating effect of firm size on the relationship between capital structure and financial distress of non-financial companies listed in Kenya. Journal of Finance and Accounting, 5(4), 151-158.

xxx. Muina, G., Castro, M., Saez, L., \& Enrique, F. (2015). The knowledge creation process: A critical examination of the SECI model.

xxxi. Musali, M. A. K. A., \& Ismail, K. N. I. K. (2014). Intellectual capital and its effect on financial performance of banks: Evidence from Saudi Arabia. International Conference on Accounting Studies, 164, 201 - 207.

xxxii. NG Data. (2017). What is customer retention? Retrieved https:/ / www.ngdata.com/ what-is-customer-retention/ .

xxxiii. Omotayo, F. O. (2015). Knowledge management as an important tool in organizational management: A review of literature. Library Philosophy and Practice (e-journal). 1238.

xxxiv. Price, J. L. (1972). Handbook of organizational measurement, heath and company. Lexington, MA: D.C.

xxxv. Shujahat, M., Hussain, S., Javed, S., Malik, M. I., Thurasamy, R., \&Ali, J. (2017).

xxxvi. Strategic management model with lens of knowledge management and competitive intelligence: A review approach. VINE Journal of Information and Knowledge Management Systems, 47(1), 55-93.

xxxvii. Statistics How To. (2018). Kaiser- Meyer-Olkin test of sampling adequacy (KMO). Retrieved from datasciencecentral.com.

xxxviii. Yamane, T. (1967). Statistics: An Introductory Analysis (2nd ed.). New York: Harper \&Row. 